\title{
It's Never Too Young to Talk about Race and Gender
}

\author{
Christia Spears Brown ${ }^{a}$ Riana Elyse Anderson ${ }^{b}$ \\ ${ }^{a}$ Department of Psychology, University of Kentucky, Lexington, KY, USA; ${ }^{b}$ Department of \\ Health Behavior and Health Education, University of Michigan, Ann Arbor, MI, USA
}

As researchers who regularly engage with parents, educators, and the media, we are often asked about the appropriate age to start having critical discussions about race and gender with children. Many adults feel uncomfortable talking about race with young children - afraid discussions of race will force children to notice race differences and inequalities for the first time (e.g., Hughes et al., 2006; Stevenson, 2014). Adults are more comfortable talking about gender with young children, but those conversations either reinforce essentialist differences between boys or girls or try to encourage girls to be more like boys (e.g., Gelman, Taylor, Nguyen, Leaper, \& Bigler, 2004).

Even researchers shy away from these research questions in young children. There is little research on how young children understand inequalities (see Brown, 2017). There is ample evidence that young children see race and gender, endorse pride and happiness with their race and gender group, and endorse positive and negative stereotypes about multiple groups. But researchers are reluctant to ask how children understand the deeper, more entrenched (and more uncomfortable) structural and systematic biases embedded in a racist, patriarchal society. This reticence may be driven by fears about IRB battles, worries about schools' and parents' disapproval, or a lack of their own awareness of this developmental process.

From our perspective, there's one big problem with this trepidation: children see identity. They see it on their skin, their hair, their clothes, their voices. They talk about it, experience it, and interact with others based on race and gender. As such, we suggest, based on the literature that does exist and our own areas of expertise, that it is never too young to talk about race and gender, and it is important to teach children - even young children - to have a critical understanding of how race and gender affect their lives and the lives of others.

\footnotetext{
KARGER 2019 S. Karger AG, Basel

Christia Spears Brown

Department of Psychology, University of Kentucky 106 B Kastle Hall

Lexington, KY 40506 (USA)

E-Mail christia.brown@uky.edu 


\section{So What Should Parents and Educators Consider in these Conversations?}

Adults must first consider the child's identity. Black children, children of Mexican immigrants, and White children need very different conversations around race and ethnicity. Cis-gender boys, cis-gender girls, transgender youth, and children who do not identify within a gender binary need very different conversations around gender/sex. The intersection of these identities is also critical. For example, Black boys and girls face different societal expectations and hurdles. Given the child's identities, these conversations will have different goals: helping children in marginalized groups cope with biases (biases that can be life threatening) and helping children in privileged groups begin to dismantle that privilege (thus, working against self-interest).

Adults then need to focus on the conversation itself. The goal for young children is to develop identity "literacy" (see Anderson \& Stevenson, 2019). This means that conversations should enhance children's ability to recognize and interpret a racial or gender encounter, help them reappraise the biased narrative, and to help them know how to effectively cope with or resolve with experience.

For young children, these conversations should be inquiry based. Educators and most parents already know how to meet children where they are and would not have them read a novel in kindergarten. Instead, when it comes to these controversial issues, ask them questions about what they notice and why it happens. This also serves as a model for children for developing critical thinking skills. Adults should also make use of each moment, since every moment of childhood is a teachable moment. This is not an example of having "the talk" for every encounter. Parents do not need to set up a special time with a special couch every time something comes up. Rather, these conversations should occur as part of daily life - while driving or walking to school, while cooking dinner, while watching television. These conversations should definitely occur when the adult sees inequalities. When you see it, say something. Pause and ask about it: what is happening, who is it affecting, when and where does this happen, and why is race and gender important in this situation?

\section{Given these Basic Guidelines, How Can Parents and Educators Make Sure these Conversations Are Actually Helpful?}

First, the adults involved need to be comfortable in their own identity and positioning. We all need to consistently self-reflect on our own attitudes. As a first step, take the Implicit Associations Test (https:/implicit.harvard.edu/implicit; Greenwald, McGhee, \& Schwartz, 1998) and reflect on the results. Ask yourself tough questions about your assumptions and unacknowledged privileges. No true growth and improvement are painless, and we all suffer a bit to make progress. This is especially true when we are trying to overcome a barrage of cultural biases we have spent a lifetime absorbing. In other words, the hard truth is that adults have to get their own "stuff" together before talking to children. Remember that our reticence and resistance are not an excuse for our children's reception. It is about practice and not just for our kids.

Second, reframe these conversations as a normative and consistent part of parenting and teaching. It is just part and parcel of how we raise children to be moral and ethical humans. Children are inundated with biased messages from society, and if we 
are not the loudest voice actively working against these messages, they are going to internalize the perspective of others. And - as we have seen from countless historic and recent examples - those perspectives can be ugly.

Finally, adults must develop comfort in discussing disparities, not just difference. We cannot just discuss differences in gender without discussing the patriarchy. We cannot just celebrate cultural holidays and Black History Month without invoking the concept of racism. These critical conversations about race and gender should occur early and often in the lives of all children, as these identities affect all children from birth. It is only when we help children interpret bias that we can help them cope with and dismantle that bias. Let us move beyond our children simply seeing identity and encourage them to find comfort discussing and acting justly towards identity as they develop. They are not only making a better world for themselves, they are making a better world for us all.

\section{References}

Anderson, R. E., \& Stevenson, H. C. (2019). RECASTing racial stress and trauma: Theorizing the healing potential of racial socialization in families. The American Psychologist, 74(1), 63-75. https://doi. org/10.1037/amp0000392

Brown, C. S. (2017). Discrimination in childhood and adolescence: A developmental intergroup approach. London, UK: Routledge. https://doi.org/10.4324/9781315208381

Gelman, S. A., Taylor, M. G., Nguyen, S. P., Leaper, C., \& Bigler, R. S. (2004). Mother-child conversations about gender: Understanding the acquisition of essentialist beliefs (p. 142). Monographs of the Society for Research in Child Development, Boston, MA: Blackwell.

Greenwald, A. G., McGhee, D. E., \& Schwartz, J. L. (1998). Measuring individual differences in implicit cognition: The implicit association test. Journal of Personality and Social Psychology, 74(6), 1464-1480. https://doi.org/10.1037/0022-3514.74.6.1464

Hughes, D., Rodriguez, J., Smith, E. P., Johnson, D. J., Stevenson, H. C., \& Spicer, P. (2006). Parents' ethnic-racial socialization practices: A review of research and directions for future study. Developmental Psychology, 42(5), 747-770. https://doi.org/10.1037/0012-1649.42.5.747

Stevenson, H. C. (2014). Promoting racial literacy in schools: Differences that make a difference. New York, NY: Teachers College Press.

Anderson, R. E., \& Stevenson, H. C. (2019). RECASTing racial stress and trauma: Theorizing the healing potential of racial socialization in families. The American Psychologist, 74(1), 63-75. https://doi. org/10.1037/amp0000392

Brown, C. S. (2017). Discrimination in childhood and adolescence: A developmental intergroup approach. London, UK: Routledge. https://doi.org/10.4324/9781315208381

Gelman, S. A., Taylor, M. G., Nguyen, S. P., Leaper, C., \& Bigler, R. S. (2004). Mother-child conversations about gender: Understanding the acquisition of essentialist beliefs (p. 142). Monographs of the Society for Research in Child Development, Boston, MA: Blackwell.

Greenwald, A. G., McGhee, D. E., \& Schwartz, J. L. (1998). Measuring individual differences in implicit cognition: The implicit association test. Journal of Personality and Social Psychology, 74(6), 1464-1480. https://doi.org/10.1037/0022-3514.74.6.1464

Hughes, D., Rodriguez, J., Smith, E. P., Johnson, D. J., Stevenson, H. C., \& Spicer, P. (2006). Parents' ethnic-racial socialization practices: A review of research and directions for future study. Developmental Psychology, 42(5), 747-770. https://doi.org/10.1037/0012-1649.42.5.747

Stevenson, H. C. (2014). Promoting racial literacy in schools: Differences that make a difference. New York, NY: Teachers College Press. 